\title{
Personal solar ultraviolet radiation dosimetry in an occupational setting across Europe
}

Keywords: UV exposure, keratinocyte cancer, occupational skin cancer, UV dosimeters

Word count: 2762, Table count: 4, Figure count: 2

M Wittlich', SM John², GS Tiplica3, CM Sălăvăstru, AI Butacu³, A Modeneses, V Paolucci ${ }^{6}$, G

D’Hauw', F Gobbas, P Sartorelli', J Macan, J Kovačićs, K Grandahl', H Moldovan'º

Institute for Occupational Safety and Health of the German Social Accident Insurance, Sankt Augustin, Germany

2Department of Dermatology, Environmental Medicine and Health Theory, University of Osnabrück,

Osnabrück, Germany

32nd Department of Dermatology, Colentina Clinical Hospital, "Carol Davila" University of Medicine and Pharmacy, Bucharest, Romania

«Pediatric Dermatology Department, Colentina Clinical Hospital, "Carol Davila” University of

Medicine and Pharmacy, Bucharest, Romania

sOccupational Medicine, Department of Biomedical, Metabolic and Neural Sciences, University of

Modena \& Reggio Emilia, Modena, Italy

'Department of Prevention, Health and Safety Unit AUSL South-East Tuscany, Viale Cimabue, Grosseto, Italy

Department of Medical Biotechnology, Unit of Occupational

Medicine, Azienda Ospedaliera Universitaria Senese, University of Siena, Italy

soccupational Health and Environmental Medicine Unit, Institute for Medical Research and Occupational Health, Zagreb, Croatia

'Department of Occupational and Social Medicine, Copenhagen University Hospital, Holbaek, Denmark

10University of Medicine, Pharmacy, Science \& Technology of Targu-Mures, Department of Occupational Medicine, Targu Mures, Romania

This article has been accepted for publication and undergone full peer review but has not been through the copyediting, typesetting, pagination and proofreading process, which may lead to differences between this version and the Version of Record. Please cite this article as doi: $\underline{10.1111 / J D V .16303}$

This article is protected by copyright. All rights reserved 
Corresponding author:

Alexandra-Irina Butacu

adabutacu@gmail.com, +40723159221

19-21 Stefan cel Mare Street, Colentina Clinical Hospital, 020125, Bucharest, Romania

Funding sources: The European Academy of Dermatology and Venereology supported this study through project no. 18 ,Joint scientific implementation and evaluation of the Healthy Skin@Work Campaign, sub-campaign skin Cancer: Safe Work Under the Sun”.

This article is protected by copyright. All rights reserved 


\section{Abstract (256 words)}

\section{Background}

Work-related solar ultraviolet radiation (UVR) is an important factor in the pathogenesis of nonmelanoma skin cancer (NMSC). The World Health Organization, through the International Agency for Research on Cancer (IARC), has classified solar UVR as a group 1 carcinogen since 2012. The main problems encountered so far in the study of occupationally induced skin cancer include the lack of accurate occupational UVR dosimetry as well as insufficient distinction between occupational and leisure UVR exposure and underreporting of NMSC.

\section{Objectives}

The aim of this study was to collect long-term individual UVR measurements in outdoor workers across European countries.

\section{Methods}

A prospective study was initiated through the European Academy of Dermatology and Venereology, Healthy Skin@Work Campaign, measuring UVR exposure doses at occupational settings of masons from five European countries. Measurements were performed for several consecutive months using the GENESIS-UV measurement system.

\section{Results}

The results identified alarming UVR exposure data. Average daily UVR doses ranged 148.40 680.48 J/m2 in Romania, 342.4-640.8 J/m2 in Italy, 165.5-466.2 J/m2 in Croatia, 41.8-473.8 $\mathrm{J} / \mathrm{m} 2$ in Denmark, and 88.15-400.22 J/m2 in Germany. Results showed an expected latitude dependence with increasing UVR yearly dosage from the north to the south of Europe.

\section{Conclusions}

This study shows that outdoor workers from EU countries included in this study are exposed to high levels of occupational solar UVR, vastly exceeding the occupational exposure limits for solar UVR exposure, considered to be 1-1.33 SED/day in the period from May to September. 
This finding may serve as an evidence-based recommendation to authorities on implementing occupational skin cancer prevention strategies.

This article is protected by copyright. All rights reserved 
PROF. GEORGE SORIN TIPLICA (Orcid ID : 0000-0002-8719-6952)

MISS ALEXANDRA IRINA BUTACU (Orcid ID : 0000-0002-1627-6912)

DR. ALBERTO MODENESE (Orcid ID : 0000-0002-0850-5615)

Article type : Original Article

\section{Introduction}

Work-related solar ultraviolet radiation (UVR) is an important factor in the pathogenesis of nonmelanoma skin cancer (NMSC), including precancerous lesions such as actinic keratosis (AK) and invasive cutaneous carcinomas, i. e. cutaneous squamous cell carcinoma (cSCC) and basal cell carcinoma (BCC) [1]. The World Health Organization (WHO) through the International Agency for Research on Cancer (IARC) has raised the issue of solar UVR being a carcinogen to humans since 1992 and has classified solar UVR as a group 1 carcinogen since 2012 [2].

In the European Union, at least 14.5 million workers are exposed to solar UVR by spending $75 \%$ of their working time outdoors [3]. High-risk professions include construction workers, roofers, road workers, fishermen, farmers, dock workers etc. The risk of developing some form of NMSC is significant higher in occupationally exposed individuals compared to the general population [4]. Recent studies have shown that outdoor workers (OW) that are exposed to solar UVR at work have twice the risk of incident $\mathrm{BCC}$ and $\mathrm{cSCC}$ compared to non-outdoor workers with less total lifetime solar UVR exposure [5,6]. Furthermore, special characteristics of BCC in OW were identified: lesions arise frequently on the "mask area" of the face and usually present a more aggressive histological subtype [7]. Occupational NMSC is characterized by long induction periods (years or even decades) and chronic actinic damage. The first signs of skin cancer may even appear after retirement following many years of cumulative occupational solar UVR exposure, becoming an important issue in our increasingly ageing population [8]. 
Costs related to treatment of NMSC can substantially be reduced by effective preventive public health strategies. Still, up to $90 \%$ of skin cancer related budget is invested in treatment and only $10 \%$ in prevention [9]. Healthy Skin@Work Campaign, raised by the European Academy of Dermatology and Venereology (EADV), is a prevention campaign whose aim it is to increase awareness of occupational skin diseases at national and international levels in Europe. Within this campaign, the sub-campaign Skin Cancer: Safe Work Under the Sun was started, focusing on outdoor workers and skin cancer risk related to their significant occupational solar UVR exposure. The goal of this sub-campaign was to improve the prevention of solar UVR exposure and reduce the occurrence of skin cancer in outdoor workers, by collecting relevant epidemiological data and advocating for EU legislation changes. Within the framework of the UN Sustainable Development Goals (SDG) 2030, the World Health Organization (WHO) and the International Labour Organization (ILO) are currently giving this topic a high priority, by developing a joint methodology to assess the global disease burden of work-related skin cancer by solar UVR exposure [10].

The main problems encountered so far in the study of occupationally induced skin cancer include the lack of accurate occupational UVR dosimetry as well as insufficient distinction between occupational and leisure UVR exposure and underreporting of NMSC [11,12]. The recently performed solar UVR dosimetry in Germany, by Wittlich et al. [13], has shown promising results

in estimating the cumulative annual solar UVR exposure in OW. The aim of this study was to collect long-term measurements of individual solar UVR exposure in groups of OW across several European countries, in order to obtain a comprehensive database of solar UVR dosage, essential for further developments of the research in the field of occupationally induced skin cancers.

\section{Material and methods}

Data collection started in 2014/2015 in Germany through the GENESIS-UV (GENeration and Extraction System for Individual exposure) study [13] and was continued using the same methodology in 2017 in other European countries (Croatia, Denmark, Italy, and Romania) that agreed to participate in a prospective study within the project no. 18 of the European Academy of Dermatology and Venereology (EADV), named „Joint scientific implementation and evaluation of the Healthy Skin@Work Campaign”.

This article is protected by copyright. All rights reserved 
The studied profession was masons. The participants were selected as volunteers from the local building companies which agreed to cooperate. The participants received financial compensation. The main work-tasks performed by the masons (during measurements) included setup and clearing of construction site, earthwork, foundation and bottom plate construction, drainage and building lateral line construction, exterior and interior wall construction, ceiling, bearer and stairs construction and sealing and residual work. In Romania, 9 OW were included from a region near Bucharest (lat. $44^{\circ} 17^{\prime} 0^{\prime \prime} \mathrm{N}$, long. $25^{\circ} 32^{\prime} 0^{\prime \prime} \mathrm{E}$ ) and from Targu Mures (lat. $46^{\circ} 32^{\prime} 44^{\prime \prime} \mathrm{N}$, long. $24^{\circ} 33^{\prime} 45^{\prime \prime} \mathrm{E}$ ). The project was conducted from April until the end of October 2017. In Italy, 4 construction workers from Tuscany region, working as masons in various construction sites in the province of Siena (lat. $43.3^{\circ} \mathrm{N}$, long. $11.3^{\circ} \mathrm{E}$ ) have been measured from the beginning of May to the end of September 2017. Since it is usual to take longer annual leave in August in Italy, measurements were not performed during this month. In Croatia, data for 4 construction industry workers, working in the vicinity of Zagreb (lat. $45.8^{\circ} \mathrm{N}$, long. $16.0^{\circ} \mathrm{E}$ ), were collected in the period from June to October 2017. In Denmark (lat. 56 ${ }^{\circ} \mathrm{N}$ ), UVR measurements were carried out nationwide in 3 masons working in various construction sites between April and October. Data from Germany was from 2014 and 2015 for 16 masons working throughout the country in various construction sites for 7 consecutive months (April to October). Since large number of measurements was already collected in Germany during the 2014/2015 period, measurements were not repeated in 2017. However, the mean sunshine duration in Germany was monitored via the German Meteorological Service (Deutscher Wetterdienst, DWD) and this data showed that the weather in the years 2014/2015 lied within the 30 -years average of the sunshine duration. Thus, due to the comparable weather conditions and the same methodology used, the German UV data was considered to be representative for other years as well and was included in this study. Nevertheless, the results for Germany are shown separately.

The occupational solar UVR exposure monitoring was performed with the GENESIS-UV methodology. GENESIS-UV is a system for decentralized measurements of individual UVR exposure mainly consisting of an electronic data logger dosimeter, a tablet PC for data storage and transmission, and accessory parts (Figure 1). The electronic dosimeters "X-201210" (Gigahertz, Turkenfeld, Germany) register the UVR irradiance in the UVA and UVB/C regions separately. Each worker was equipped with a dosimeter to be worn on the left upper arm

This article is protected by copyright. All rights reserved 
during working hours. The left upper arm was chosen due to wearing comfort and compliance. The dosimeter was carried in an upper arm holder, which had been manufactured in cooperation with a medical supply store, and a positive feedback from workers was received. The participants were instructed to wear dosimeters over their clothes. UVR exposure was constantly registered from 7.00 a.m. to 5.00 p.m. for five days per week (before 7.00 a.m. and after 5.00 p.m. available UV dose was considered to be small) [13]. The workers were instructed not to take off the dosimeters during the working time and thus the measurements reflect total exposure at workplace, including exposure during lunch breaks. Once a week the dosimeters have to be connected to the tablet PC to transfer the data to the data server in Germany. For data analysis, data was rearranged to yield a daily average value per month. Therefore, each data point was analysed for means of plausibility. The dosimeter records a combination of accelerometer and magnetic field data along with the UV exposure data with a resolution of one second. The acceleration sensor shows periods of rest or movement very sensitively. Furthermore, the UV data pattern of a dosimeter differs between resting periods and periods of movement. Thus, the periods of rest, e.g. if a worker forgot to take his dosimeter or left it resting in the sun, could be precisely identified from both the absolute value of the acceleration vector and the data pattern of a dosimeter. After carefully examining these two types of measurements, daily episodes where the dosimeter was virtually resting were excluded from analysis. A daily value was then calculated by summarizing the single second values of UV dosage measurements.

\section{Statistical analysis}

A descriptive analysis of data was performed. Daily values of all test persons of a certain month within a country were used to calculate a daily average per month, as well as standard deviation, standard error, minimum and maximum values, and range of values recorded in each month.

In addition to descriptive analysis, yearly exposure values for each country were calculated. Assuming a certain number of monthly working days (April, June, September 20 days, and May, July, August, October 21 days, respectively), a monthly exposure value $m_{i}$ for month $i$ was calculated by multiplying mean exposure value for a given month by the corresponding number of working days. With the help of a seasonal factor (Table 1), the sum of the above-mentioned data was extrapolated to a value for the entire year using the following formula:

This article is protected by copyright. All rights reserved 
$\frac{\sum_{i} m_{i} f_{s}^{(i)}}{\sum_{i} f_{s}^{(i)}}$

Here $f_{s}^{(i)}$ denotes the seasonal factor for month $i$. Only mean values calculated from at least 8 valid measurements contributed to the yearly exposure estimation, i.e. for each country the summations in formula are indexed over the months for which $\mathrm{N}>7$ in Tables 2 and 3.

Exposure to solar UVR is presented in $\mathrm{J} / \mathrm{m}^{2}$ and standard erythemal dose (SED; $1 \mathrm{SED}=100$ $\left.\mathrm{J} / \mathrm{m}^{2}\right)$.

\section{Results}

Table 2 shows the detailed information on the UVR recorded doses for data collected in 2017 (Romania, Italy, Croatia, and Denmark). Data for Germany, collected in 2014/2015, is shown in Table 3. Table 4 shows the extrapolated yearly exposure and Figure 2 latitude dependency of UVR average daily exposures across countries.

In Romania, average daily UVR doses ranged from $148.40 \mathrm{~J} / \mathrm{m}^{2}$ in October to $680.48 \mathrm{~J} / \mathrm{m}^{2}$ in April. Extrapolating these results, a yearly sum of 633 SED was calculated.

In Italy, average daily UVR doses ranged from $342.4 \mathrm{~J} / \mathrm{m}^{2}$ in July to $640.8 \mathrm{~J} / \mathrm{m}^{2}$ in May. A yearly sum of 671 SED was calculated for Italy.

In Croatia, average daily UVR doses peaked in July (mean value of $466.2 \mathrm{~J} / \mathrm{m}^{2}$ ), while lowest values where recorded in October (mean value of $165.5 \mathrm{~J} / \mathrm{m}^{2}$ ). Mean daily UVR exposures ranged from 0.4 SED (OW4) to 5.1 SED (OW1), indicating a high between-worker variability. A yearly sum of 519 SED was calculated for Croatia.

In Denmark average daily UVR doses ranged from $41.8 \mathrm{~J} / \mathrm{m}^{2}$ in October (the Danish summer season ends in September) to $473.8 \mathrm{~J} / \mathrm{m}^{2}$ measured in July, representing a mean daily UV exposure ranging between 0.4 and 4.7 SED. Note that for personal reasons DOW2 wore the dosimeter attached to his hat (and not on the upper arm). A yearly sum of 463 SED was calculated for Denmark.

In Germany, average daily UVR doses ranged from $88.15 \mathrm{~J} / \mathrm{m}^{2}$ in October to $400.22 \mathrm{~J} / \mathrm{m}^{2}$ in May. A yearly sum of 504 SED was calculated for Germany.

Results showed expected latitude dependence with increasing UVR yearly dosage from north to the south of Europe (Table 3, Figure 2).

This article is protected by copyright. All rights reserved 


\section{Discussion}

In this study, solar UVR exposure data were collected in outdoor workers from several European geographical regions, showing hazardous levels of solar UVR exposure in clear violation of the international threshold dosages [10]. Solar UVR exposure monitoring was performed using personal dosimeters. It was considered that workers must not be impaired by wearing the dosimeter, as this would falsify their behavior. In a study in Germany it has been shown that the left upper arm resembled the chest position [14], and exposure of other body parts can be approximated by the correction factors [13]. The participants were instructed to wear the dosimeters over their clothes, thus measurements should represent the doses that would be received by the unprotected skin. The methodology allowed differentiation between periods of rest and movement, thus it was possible to detect periods when a worker, most likely, did not wear the dosimeter, and exclude these periods from the analysis.

The yearly occupational UVR exposure dose of 633 SED in Romania shown in this study is unexpectedly high. This is especially true when compared to a previous German study where the annual UVR exposure was estimated at 130 SED in the general population and an additional 170 SED in outdoor workers [15]. Data previously gathered in Romania showed daily UVR doses ranging from 1.8 SED (farm car driver) to 19.0 SED (agriculture worker) with maximum UVR doses recorded between 10:00 am to 4:00 pm [16]. In Denmark, the average annual UVR exposure was previously estimated to be 168 SED in the general population and 224 SED in outdoor workers, based on a previous dosimetry study from 2005. In contrast, a more recent dosimetry study from 2018 showed higher levels of semi-annual solar UVR exposure in Danish outdoor workers as well as a significant variation between several outdoor occupations [17]. Danish roofers were the highest exposed with average doses of 4.7 SED per day in times of maximum solar activity [17]. These measurements were performed during the Danish summer season, on the wrist, and only included UVB [17]. In two previous studies, the average daily UVR erythemal dose received by a construction worker from the Tuscany region ranged between 3.5 and 6.5 SED, exceeding approximately 3-6 times the international occupational exposure limits for daily solar UVR exposureof 1-1.33 SED [10, 18, 19]. Regarding Croatia, these are the first occupational solar UVR exposure data in OW, indicating daily doses between 3.6 and 4.7 SED during the months of June, July, and August in masons working near Zagreb. However, 
as Croatia and Italy each include regions with substantially different climates (mountainous, continental, Mediterranean), occupational UVR dosimetryshould be collected in different climate regions for a complete exposure map in these countries. A former study found that German construction workers were exposed to daily occupational UVR doses of 215 SED[14], which is less than half of the dose recently measured with GENESIS-UV In this study, German masons are exposed to a maximum daily dose of 4 SED and a yearly dose of 504 SED as a clear indication of excess exposure. Also, the exposure limit value [10] is regularly exceeded by a factor 4 in all the observed workers. The results of this study confirm the expected latitude dependence of occupational solar UVR exposures (Table 3, Figure 2).

Considering construction workers in Denmark, Italy and Croatia, the results of the measurement campaign is influenced by the relatively small number of involved workers compared to the measurement campaigns performed in the other involved European countries. While one of the study strengths is a large number of continuous measurements per worker, relatively small number of workers in some countries (e.g. $\mathrm{N}=3$ in Denmark and $\mathrm{N}=4$ in Italy and Croatia) presents a study limitation, as well as a notable between-worker variability in some cases. Including more workers would improve the accuracy of the yearly exposure estimation for these countries. The comparison of the data on masons with data found in the literature is hampered by the fact that most of the studies do not discriminate between the various occupations and work tasks in the construction industry. According to the German data, masons are among the construction workers with the highest UVR exposure. Thus, insufficient differentiation of exposure to UVR in construction workers entails a risk of exposure misclassification.

Some statistical limitations should also be mentioned for this study. Standard errors were in this study calculated as in the case of independent observations. Since some degree of autocorrelation might be expected due to the similar meteorological conditions for observations close in time and perhaps similar working conditions for the measurements of the same worker, these standard errors might be underestimated.

\section{Conclusions}

This study shows that outdoor construction workers from EU countries included in this study are exposed to high levels of occupational solar UVR, vastly exceeding the occupational exposure limits for solar UVR exposure, considered to be 1-1.33 SED/day in the period from May to 
September. This finding serves as an evidence-based recommendation to authorities on implementing occupational skin cancer prevention strategies. Future studies and interactions with policy makers will serve as indispensable steps in changing legislation and notification strategies in high-risk professions throughout Europe. Additionally, a comprehensive European database on occupational skin cancer may serve as foundation in future guidelines development.

Acknowledgments: The European Academy of Dermatology and Venereology supported this study through project no. 18 ,Joint scientific implementation and evaluation of the Healthy Skin@Work Campaign, sub-campaign skin Cancer: Safe Work Under the Sun". Authors acknowledge the support from COST Action CA16216 "Network on the Coordination and Harmonisation of European Occupational Cohorts (OMEGA-NET)" and also from COST Action TD1206 "StanDerm - Development and Implementation of European Standards on Prevention of Occupational Skin Diseases".

\section{All authors have contributed equally.}

\section{References}

1. Watson M, Holman DM, Maguire-Eisen M. Ultraviolet radiation exposure and its impact on skin cancer risk. Ed. WB Saunders. InSeminars in oncology nursing 2016 Aug 1; Vol. 32, No. 3, pp. 241-254.

2. IARC Monographs on the Evaluation of Carcinogenic Risks to Humans, volume 100D, 2012. Available online: http://monographs.iarc.fr/ENG/Monographs/vol100D/index.php [Last accessed on 18 February 2019].

3. Kauppinen T, Toikkanen J, Pedersen D, Young R, Ahrens W, Boffetta P, Hansen J, Kromhout H, Blasco JM, Mirabelli D, de la Orden-Rivera V. Occupational exposure to carcinogens in the European Union. Occupational and environmental medicine. 2000 Jan 1;57(1):10-8.

4. Thieden E, Philipsen PA, Heydenreich J, Wulf HC. UV radiation exposure related to age, sex, occupation, and sun behavior based on time-stamped personal dosimeter readings. Archives of dermatology. 2004 Feb 1;140(2):197-203.

5. Schmitt J, Haufe E, Trautmann F, Schulze HJ, Elsner P, Drexler H, Bauer A, Letzel S, John SM, Fartasch M, Brüning T. Occupational Uv-exposure is a Major Risk Factor for Basal Cell Carcinoma: Results of the Population-based Case-control Study Fb-181. Journal of occupational and environmental medicine. 2018 Jan 1;60(1):36-43.

This article is protected by copyright. All rights reserved 
6. Schmitt J, Haufe E, Trautmann F, Schulze HJ, Elsner P, Drexler H, Bauer A, Letzel S, John SM, Fartasch M, Brüning T. Is ultraviolet exposure acquired at work the most important risk factor for cutaneous squamous cell carcinoma? Results of the population- based case-control study FB- 181. British Journal of Dermatology. 2018 Feb 1;178(2):462-72.

7. Salavastru CM, Ulrich C, Cretu S, Moldovan HR, Tiplica GS. The experience of a tertiary referral centre in Romania on basal cell carcinomas in outdoor workers: why to assess?. Journal of the European Academy of Dermatology and Venereology. 2016 Apr;30:12-6.

8. Diepgen TL, Fartasch M, Drexler H, Schmitt J. Occupational skin cancer induced by ultraviolet radiation and its prevention. British Journal of Dermatology. 2012 Aug 1;167(s2):7684.

9. Gordon LG, Rowell D. Health system costs of skin cancer and cost-effectiveness of skin cancer prevention and screening: a systematic review. European Journal of Cancer Prevention. 2015 Mar 1;24(2):141-9.

10. Paulo MS, Adam B, Akagwu C, Akparibo I, Al-Rifai RH, Bazrafshan S, Gobba F, Green AC, Ivanov I, Kezic S, Leppink N. WHO/ILO work-related burden of disease and injury: Protocol for systematic reviews of occupational exposure to solar ultraviolet radiation and of the effect of occupational exposure to solar ultraviolet radiation on melanoma and non-melanoma skin cancer. Environment international. 2019 May 1;126:804-15.

11. Moldovan HR, Voidazan ST, John SM, Weinert P, Moldovan G, Vlasiu MA, Szasz ZA, Tiplica GS, Szasz S, Marin AC, Salavastru CM. The Eastern European experience on occupational skin diseases. Make underreporting an issue?. Journal of the European Academy of Dermatology and Venereology. 2017 Jun;31:5-11.

12. Ulrich C, Salavastru C, Agner T, Bauer A, Brans R, Crepy MN, Ettler K, Gobba F, Goncalo M, Imko-Walczuk B, Lear J, Macan J, Modenese A, Paoli J, Sartorelli P, Stageland K, Weinert P, Wroblewski N, Wulf HC, John SM. The European Status Quo in legal recognition and patient- care services of occupational skin cancer. Journal of the European Academy of Dermatology and Venereology. 2016 Apr 1;30(S3):46-51.

13. Wittlich, M., Westerhausen, S., Kleinespel, P., Rifer, G., Stöppelmann, W. An approximation of occupational lifetime UVR exposure: Algorithm for retrospective assessment and current measurements. J. Eur. Acad. Dermatol. Venereol. 2016, 30, 27-33.

This article is protected by copyright. All rights reserved 
14. Knuschke, P., Unverricht, I., Ott, G., Janssen, M. [Personenbezogene Messung der UVExposition von Arbeitnehmern im Freien]; Aufl. Forschungsprojekt F 1777, Schriftenreihe der Bundesanstalt für Arbeitsschutz und Arbeitsmedizin, 2007, ISBN 978-3-88261-060-4

15. Diepgen TL, Brandenburg S, Aberer W, Bauer A, Drexler H, Fartasch M, Malte John S, Krohn S, Palfner S, Römer W, Schuhmacher-Stock U. Skin cancer induced by natural UVradiation as an occupational disease-Requirements for its notification and recognition. Journal der Deutschen Dermatologischen Gesellschaft. 2014 Dec;12(12):1102-6.

16. Butacu AI, Moldovan H, Wittlich M, John SW, Tiplica GS, Salavastru CM. UV occupational exposure in Romania. 15th EADV Spring Symposium, 3-6 May 2018, Budva, Montenegro. CD Abstract. ISBN: 978-88-942552-2-5.

17. Grandahl K, Eriksen P, Ibler KS, Bonde JE, Mortensen OS. Measurements of Solar Ultraviolet Radiation Exposure at Work and at Leisure in Danish Workers. Photochem Photobiol. 2018 Jul;94(4):807-814.

18. Miligi L, Benvenuti A, Legittimo P, Badiali AM, Cacciarini V, Chiarugi A, Crocetti E, Alberghini Maltoni S, Pinto I, Zipoli G, Grifoni D, Carnevale F, Pimpinelli N, Cherubini Di Simplicio F, Poggiali S, Sartorelli P, Sirna R, Amati R, Centi L, Festa G, Fiumalbi C, Fedi A, Giglioli S, Mancini R, Panzone T, Petrioli G, Trombetti A, Volpi D. Solar ultraviolet radiation risk in outdoor workers: a specific project of Tuscany Region (Italy). Epidemiol Prev. 2013 JanFeb;37(1):51-9.

19. Siani AM, Casale GR, Sisto R, Colosimo A, Lang CA, Kimlin MG. Occupational exposures to solar ultraviolet radiation of vineyard workers in Tuscany (Italy). Photochemistry and photobiology. $2011 \mathrm{Jul} ; 87(4): 925-34$.

Table legends

Table 1 - Values of the seasonal factor $f_{s}$ on the northern hemisphere

Table 2 - Daily erythemal UVR exposure [J/m2] measured for outdoor workers (masons) in 2017 in different European countries

This article is protected by copyright. All rights reserved 
For each country and month, descriptive statistics for all valid measurement days obtained from all included workers is shown. $\mathrm{N}$ : number of valid measurement days per month for all workers from the same country; SD: standard deviation; SE: standard error.

Table 3 - Daily erythemal UVR exposure [J/m2] measured for outdoor workers (masons) in 2014/2015 in Germany

For each month, descriptive statistics for all valid measurement days obtained from all included workers is shown. N: number of valid measurement days per month for all included workers; SD: standard deviation; SE: standard error.

Table 4 - Yearly exposure of workers. The data were extrapolated from average values of the monthly exposure

* Latitude taken for Bonn, for the whole country ranges between 47-55

This article is protected by copyright. All rights reserved 
Figure legends.

Figure 1: GENESIS-UV (GENeration and Extraction System for Individual exposure) system for measuring individual UVR exposure. The measuring equipment consists mainly of an electronic data logger dosimeter, to be worn on the left upper arm, a tablet PC for data storage and transmission, and accessory parts.

Figure 2: Average daily exposure in standard erythemal dose (SED) units across countries. For each country and month, average daily exposure is obtained from all valid measurement days of all included workers. For each country, only months with at least 8 valid measurements are shown. Data was collected in 2014/2015 (Germany) and in 2017 (all other countries).

This article is protected by copyright. All rights reserved 
Table 1 - Values of the seasonal factor $f_{s}$ on the northern hemisphere

\begin{tabular}{|c|cc|}
\hline Month & \multicolumn{2}{|c|}{ Seasonal factor fS } \\
\hline January & 0.015 & $(1.5 \%)$ \\
\hline February & 0.025 & $(2.5 \%)$ \\
\hline March & 0.055 & $(5.5 \%)$ \\
\hline April & 0.100 & $(10.0 \%)$ \\
\hline May & 0.150 & $(15.0 \%)$ \\
\hline June & 0.185 & $(18.5 \%)$ \\
\hline July & 0.170 & $(17.0 \%)$ \\
\hline August & 0.140 & $(14.0 \%)$ \\
\hline September & 0.090 & $(9.0 \%)$ \\
\hline October & 0.045 & $(4.5 \%)$ \\
\hline November & 0.015 & $(1.5 \%)$ \\
\hline December & 0.010 & $(1.0 \%)$ \\
\hline \hline
\end{tabular}

This article is protected by copyright. All rights reserved 
Table 2 - Daily erythemal UVR exposure [J/m2] measured for outdoor workers (masons) in 2017 in different European countries

\begin{tabular}{|c|c|c|c|c|c|c|c|}
\hline \multicolumn{7}{|c|}{ Daily Values [J/m²] } \\
\hline \multicolumn{7}{|c|}{ Romania } \\
\hline & April & May & June & July & August & September & October \\
\hline N & 8 & 159 & 116 & 96 & 106 & 111 & 127 \\
\hline $\begin{array}{c}\text { Mean } \\
\text { UVR }\end{array}$ & 680.48 & 368.05 & 450.09 & 451.95 & 360.52 & 258.44 & 148.40 \\
\hline SD & 258.79 & 283.84 & 284.87 & 267.52 & 287.19 & 165.92 & 141.88 \\
\hline SE & 91.49 & 22.51 & 26.45 & 27.30 & 27.89 & 15.74 & 12,58 \\
\hline Min & 457.79 & 2.38 & 1.55 & 9.45 & 17.67 & 1.24 & 0,27 \\
\hline Max & 1161.94 & 1161.78 & 1323.68 & 1205.49 & 2108.28 & 918.21 & 617,25 \\
\hline Range & 704.14 & 1159.39 & 1322.12 & 1196.03 & 2090.61 & 916.97 & 616,98 \\
\hline & & & & \multicolumn{7}{|c|}{ Italy } & & \\
\hline N & 0 & 20 & 27 & 6 & - & 3 & 0 \\
\hline $\begin{array}{c}\text { Mean } \\
\text { UVR }\end{array}$ & - & 640.83 & 451.08 & 342.38 & - & 572.46 & - \\
\hline SD & - & 426.29 & 271.44 & 273.92 & - & 204.56 & - \\
\hline SE & - & 95.32 & 52.24 & 111.83 & - & 118.10 & - \\
\hline Min & - & 120.51 & 7.80 & 55.96 & - & 344.40 & - \\
\hline Max & - & 1556.78 & 998.65 & 837.19 & - & 739.77 & - \\
\hline Range & - & 1436.26 & 990.84 & 781.22 & - & 395.37 & - \\
\hline & & - & 398.60 & 466.21 & 358.77 & 195.58 & 165.53 \\
\hline N & 0 & 0 & 39 & 48 & 49 & 34 & 31 \\
\hline $\begin{array}{c}\text { Mean } \\
\text { UVR }\end{array}$ & - & - & 308.52 & 367.06 & 333.02 & 217.36 & 147.94 \\
\hline SD & - & - & 49.40 & 52.98 & 47.58 & 37.27 & 26.57 \\
\hline SE & - & - & 16.42 & 6.65 & 8.25 & 2.11 & 3.27 \\
\hline Min & - & - & 1201.05 & 1132.23 & 1038.02 & 757.54 & 537.86 \\
\hline Max & - & - & & & & \\
\hline
\end{tabular}

This article is protected by copyright. All rights reserved 


\begin{tabular}{|c|c|c|c|c|c|c|c|}
\hline Range & - & - & 1184.63 & 1125.58 & 1029.77 & 755.42 & 534.58 \\
\hline \multicolumn{7}{|c|}{ Denmark } \\
\hline N & 8 & 36 & 23 & 2 & 24 & 11 & 9 \\
\hline $\begin{array}{c}\text { Mean } \\
\text { UVR }\end{array}$ & 207.97 & 393.38 & 473.70 & 715.76 & 285.93 & 203.96 & 41.76 \\
\hline SD & 105.65 & 256.53 & 293.15 & 129.26 & 203.04 & 102.80 & 37.49 \\
\hline SE & 37.35 & 42.76 & 61.13 & 91.40 & 41.45 & 30.99 & 12.50 \\
\hline Min & 5.78 & 33.33 & 21.94 & 624.36 & 11.43 & 81.14 & 4.57 \\
\hline Max & 324.32 & 914.68 & 961.52 & 807.17 & 756.16 & 381.93 & 128.17 \\
\hline Range & 318.54 & 881.34 & 939.57 & 182.80 & 744.72 & 300.78 & 123.60 \\
\hline
\end{tabular}

For each country and month, descriptive statistics for all valid measurement days obtained from all included workers is shown. N: number of valid measurement days per month for all workers from the same country; SD: standard deviation; SE: standard error. 
Table 3 - Daily erythemal UVR exposure [J/m2] measured for outdoor workers (masons) in 2014/2015 in Germany

\begin{tabular}{|c|c|c|c|c|c|c|c|}
\hline \multicolumn{7}{|c|}{ Daily Values $\left[\mathbf{J} / \mathbf{m}^{2}\right]$} \\
\hline \multicolumn{9}{|c|}{ Germany } \\
\hline & April & May & June & July & August & September & October \\
\hline $\mathrm{N}$ & 97 & 126 & 150 & 177 & 97 & 135 & 119 \\
\hline $\begin{array}{c}\text { Mean } \\
\text { UVR }\end{array}$ & 338.87 & 400.22 & 380.66 & 398.74 & 334.79 & 216,76 & 88,15 \\
\hline SD & 231.10 & 241.20 & 320.14 & 371.95 & 261.55 & 164,65 & 88,93 \\
\hline SE & 23.46 & 21.49 & 26.14 & 27.96 & 26.56 & 14,17 & 8,15 \\
\hline Min & 0.14 & 12.29 & 0.31 & 1.29 & 0.70 & 2,59 & 0,50 \\
\hline Max & 991.39 & 1343.19 & 1513.27 & 1628.20 & 1024.50 & 896,02 & 531,95 \\
\hline Range & 991.25 & 1330.90 & 1512.96 & 1626.91 & 1023.81 & 893,43 & 531,45 \\
\hline
\end{tabular}

For each month, descriptive statistics for all valid measurement days obtained from all included workers is shown. N: number of valid measurement days per month for all included workers; SD: standard deviation; SE: standard error. 
Table 4 - Yearly exposure of workers. The data were extrapolated from average values of the monthly exposure

\begin{tabular}{|c|c|c|}
\hline Country & Latitude & $\begin{array}{c}\text { Yearly exposure value } \\
\text { (SED) }\end{array}$ \\
\hline Denmark (2017) & 56 & 463 \\
\hline Germany* (2014/2015) & $51^{*}$ & 504 \\
\hline Croatia (2017) & 45.8 & 519 \\
\hline Romania (2017) & 45.25 & 633 \\
\hline Italy (2017) & 34.3 & 671 \\
\hline
\end{tabular}

* Latitude taken for Bonn, for the whole country ranges between 47-55 


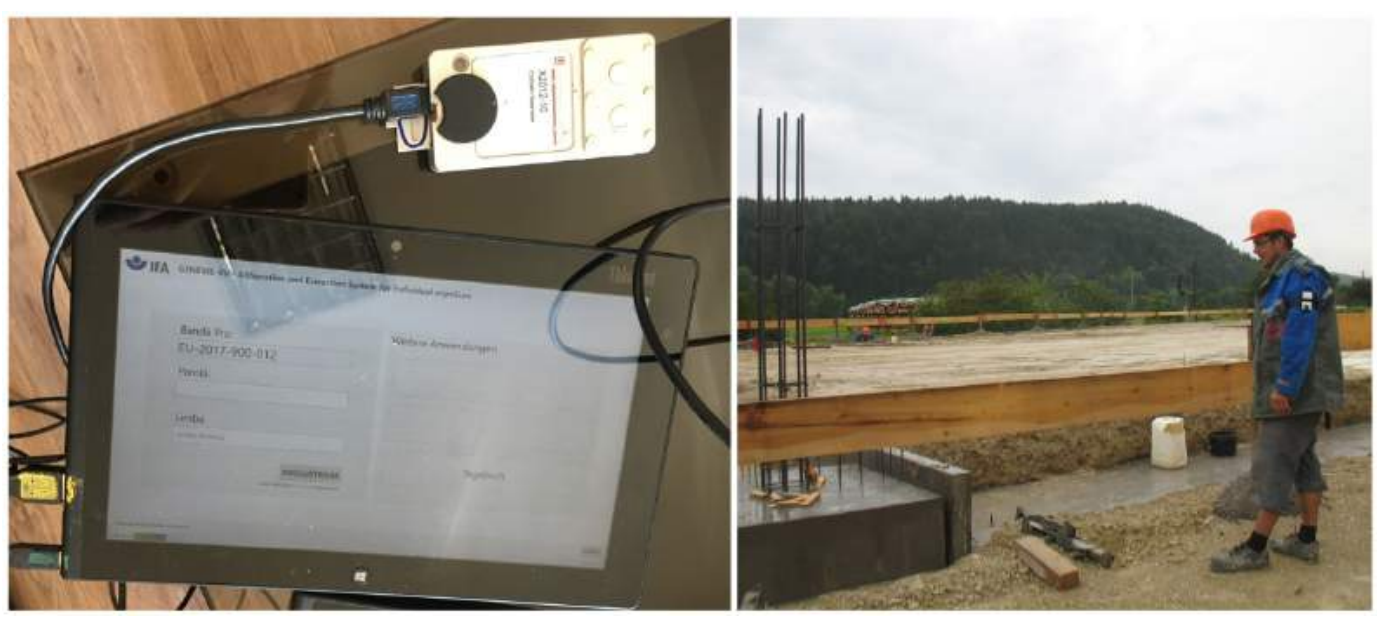

jdv_16303_f1.jpg 


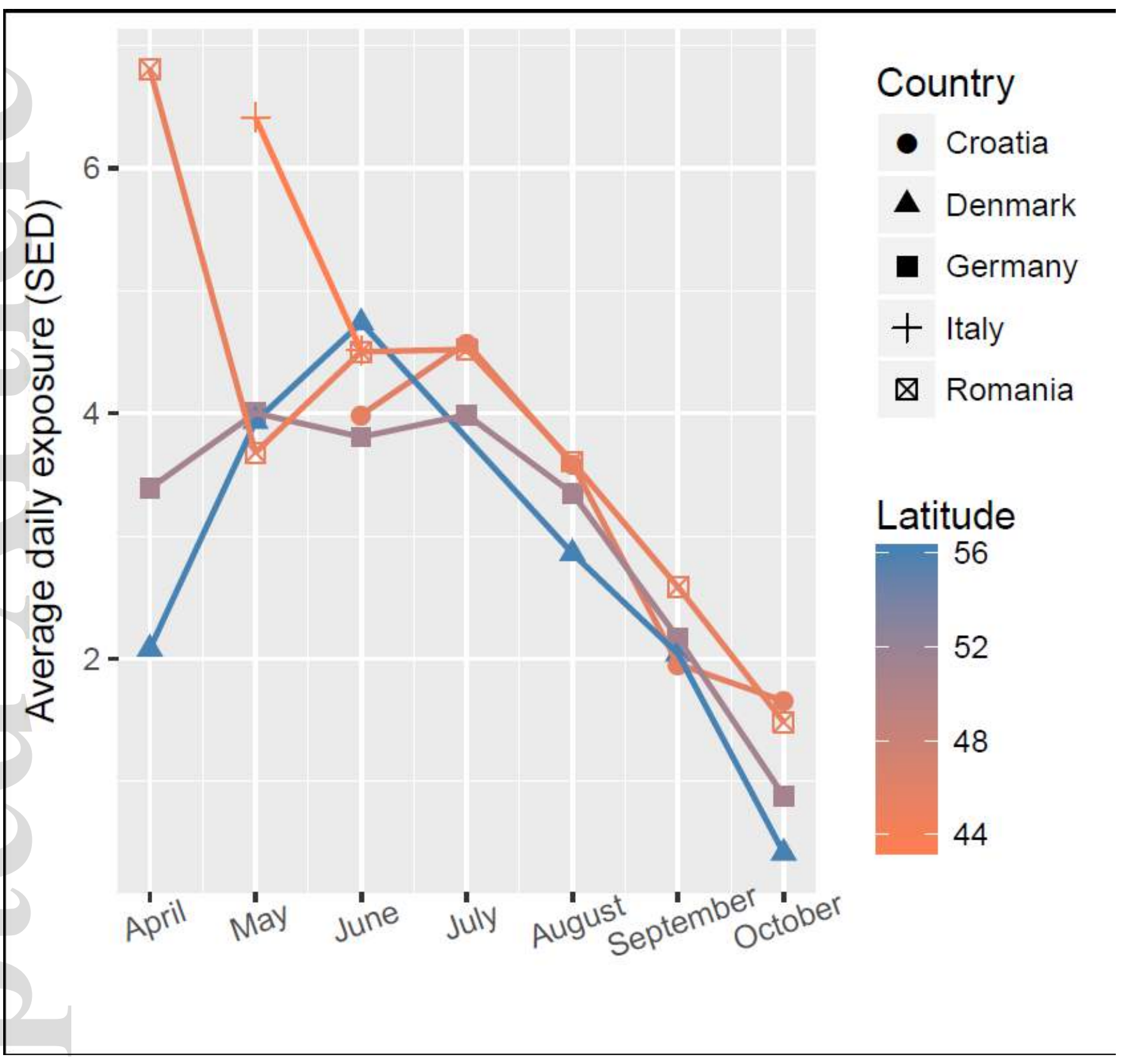

jdv_16303_f2.png 